\title{
Estimation of Residual Antibiotics in Pharmaceutical Effluents and their Fate in Affected Areas
}

\author{
Shoaib Hussain ${ }^{1 *}$, Muhammad Naeem², Muhammad Nawaz Chaudhry ${ }^{1}$ \\ ${ }^{1}$ College of Earth and Environmental Sciences, University of the Punjab, Lahore Pakistan \\ ${ }^{2}$ Applied Chemistry Research Centre (ACRC), Pakistan Council of Scientific and Industrial Research (PCSIR) \\ Labs Complex, Lahore, Pakistan
}

Received: 28 June 2014

Accepted: 31 December 2015

\begin{abstract}
Contamination levels of antibiotics, namely ofloxacin (OFL), ciprofloxacin (CIP), levofloxacin (LEV), oxytetracycline (OTC), and doxycycline (DOX), were quantified in wastewater, soil, plants, and underground water of surrounding areas of the pharmaceutical industry in Lahore. HPLC with a DAD detector, C-18 column, and solid-phase cartridges were used to analyze antibiotic residues. In wastewater CIP was 3.0-5.25 $\mathrm{mg} / \mathrm{L}$, LEV was 0-6.20 mg/L, OFL was 2.45-4.12 mg/L, OTC was 0-9.40 mg/L, and DOX was 1.58-6.75 $\mathrm{mg} / \mathrm{L}$. From wastewater, antibiotics accumulate in environmental segments and impact human health. From wastewater, antibiotics accumulate in soil and plants and percolate to groundwater. The contamination level was 1,000 times higher in wastewater samples than other samples, as it is the primary source of antibiotics entering the environment. After wastewater, soil was the most contaminated environmental segment and groundwater was least contaminated by these residues, but water is very important as it is source of accumulation of antibiotics for human and animal bodies as well as to plants.
\end{abstract}

Keywords: contamination, environment, pharmaceutical wastewater, residual antibiotics

\section{Introduction}

Antibiotic residues in industrial and hospital wastewater enter the environment. These residues enter soil, leach to groundwater, and accumulate in plants [1-5]. After entering the food chain they enter the human body through animal meat or milk and threaten human health [6]. The broad use of pharmaceutical compounds for treatments of diseases is considered to be a scary human health threat resulting not only in the appearance and

*e-mail: shoaibhussainsatti@yahoo.com spread of resistant bacteria, but also in other environmental damage [7-9]. Antibiotics are used to treat and prevent infectious diseases in humans and animals. Antibiotics are naturally occurring, semi-synthesized or synthesized complexes with antimicrobial action. Three threats originating from excessive application of antibiotics to treat environmental pollution are: by original materials or byproducts, the secondary influence on health through resilient micro-organisms, and direct biological injury [10-12]. Moreover, the impacts on the biotic environs are alarming. Fluoroquinolones like ciprofloxacin (CIP), levofloxacin (LEV), ofloxacin (OFL) and Tetracyclines like oxytetracycline (OTC), and doxycycline (DOX) 
antibiotics are broad-spectrum antibiotics as they are affective at controlling a wide variety of infectious diseases. These antibiotics are prepared in large quantities due to their wide use in human and veterinary treatments. Their use in animal-derived food production sites can lead to antibiotic resistance and food residues.

\section{Sources of Antibiotics in the Environment}

The excretion of unabsorbed antibiotics by humans and animals is one of the main causes of antibiotics in the environment [7]. Additional sources include the discarding of unused antibiotics and leftovers from medicinal industrial practices [13]. Residential and commercial facilities are identified suppliers of antibiotics to community wastewater [14].

Supplementary possible contributors of antibiotics to surface and shallow waters are discharges from wastewater treatment plants (WWTPs) $[2,14,15]$ and manufacturing facilities like pharmaceutical plants and superficial runoff from concentrated animal feeding operations (CAFOs) $[13,16]$. Frequent contact of the bacteria with even minor concentrations of antibiotics can cause the occurrence or persistence of resilient bacteria strains [17-21]. Earlier research showed that the maximum of the antibiotics in the environment showed straight hazardous properties $[22,23]$ and bad effects [24-26].

\section{Fate and Occurrence of Antibiotics in the Environment}

Numerous procedures can disturb the fate and means of transport of carbon-based complexes in the environment, including sorption, biotic alteration, and abiotic alteration [27-30]. Information about chemical

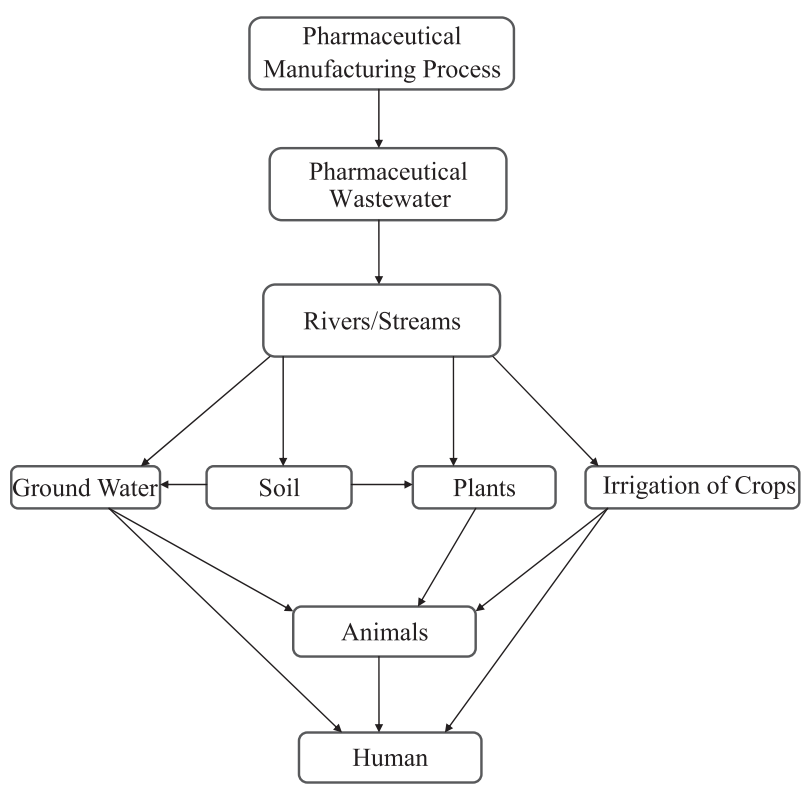

Fig. 1. Transport of Pharmaceutical compounds from pharmaceutical wastewater to the environment and humans. properties and structures of complexes can allow for initial approximation of their fate and persistence. The persistence and movement of antibiotics in the ecosystem have been determined as: sulfonamides and fluoroquinolones are the most persistent, followed by macrolides; tetracyclines can persist for comparatively extensive ages in the absence of sunlight [27]. Tetracyclines and fluoroquinolones are easily adsorbed by soils, sediments, and/or manure slurry $[2,31]$. Estimation in liquid samples is mostly connected to persistence and transport in the marine environment [30, 32-34].

\section{Fate of Antibiotics in the Environment of Pakistan}

Pakistan has more than 600 pharmaceutical industries for secondary manufacturing of pharmaceutical compounds [35]. These industries, surrounded by urban populations, are located in different areas of large cities of Pakistan, like Lahore. None of these industries has treatment facility for the removal of antibiotics and other pharmaceutical compounds from their wastewater. Usually wastewater from pharmaceutical industries drains into the sanitation system that in turn enters canals used for crop irrigation. On the other hand, some amount of wastewater reaches ponds of stagnant water. These ponds are also a source of drinking water for animals. Aquatic life is affected the most by this practice. So the most immediate need is to develop an easy, economic, reproducible, reliable, precise, and accurate method of quantification of residual levels of antibiotics in such samples.

Tetracycline for veterinary and fluoroquinolones for humans are the most prescribed antibiotics in Pakistan. Oxytetracycline (OTC) and doxycycline (DOX) from the tetracycline family of antibiotics and ciprofloxacin (CIP), levofloxacin (LEV), and ofloxacin (OFL) from the fluoroquinolones family of antibiotics were selected for this study. The selection of antibiotics was based on five aspects: 1) frequency of use, 2) analytical instruments available in the laboratory, 3) identified or assumed environmental impact, 4) presence in aqueous environments, and 5) previous detections in wastewater, surface water, and groundwater $[27,36]$.

\section{Objectives of this Study}

In our previous research of residual antibiotic determination in soil, plants, and groundwater we found environmental segments affected by these pollutants, so it was necessary to evaluate the sources of antibiotics entering the environment. The objective of this study is to validate the quantification method for residual levels of antibiotics in discharge from potential sources (pharmaceutical industries), and to determine limits of detection (LOD); limits of quantification (LOQ) of CIP, LEV, OFL, OTC, and DOC antibiotics; and to use this method to determine residual antibiotic levels in industrial effluent wastewater and compare these with the levels of antibiotic accumulation in soil and plants affected by these 
effluents, and in groundwater of the surrounding areas of the industrial zones in Lahore.

\section{Experimental}

\section{Chemicals and Reagents}

Reference standards used for HPLC analysis of OXT, DOX, CIP, LEV, and OFL were purchased from USP reference standards, USA. HPLC-grade Acetonitrile and methanol, orthophosphoric acid (OPA), chloroform, and ammonia solution were purchased from Merck.

\section{Equipment}

We used an HPLC system equipped with a DADDetector, C-18 column (Shimadzu Scientific Instruments, Kyoto, Japan), Vacuum Pump (Spectrum Scientific, UK), and Filtration assembly (Sartorius, Germany) for mobile phase filtration, and Ultrasonic bath (Elema Germany), and syringe filters for sample and standard solutions filtration.

\section{Quantitative Analysis and HPLC Validation}

Residual quantification of antibiotics was performed on the HPLC system and the method was validated as per International Conference on Harmonization guidelines.
Five concentrations of each antibiotic standard ranging from 50 to $8,000 \mathrm{ng} / \mathrm{mL}$ were prepared and analyzed by HPLC. The calibration curve was generated by plotting peak areas against concentrations. The average area of each concentration was applied for linearity and statistical analysis. The detection limit of each antibiotic was calculated as a signal-to-noise ratio method. The stability of stock solutions of the selected antibiotics was evaluated at room temperature $\left(25^{\circ} \mathrm{C}\right)$ for 24 hours and at $5^{\circ} \mathrm{C}$ for seven days, respectively. After completion of the storage time period, the stability was analyzed by comparison of the HPLC results with those of freshly prepared solution. In a similar way, a working mixed standard solution (1 $\mu \mathrm{g} / \mathrm{mL}$ of each antibiotic) was checked. The effect on the peak areas and the validations in the retention times were evaluated by change of $\pm 5 \%$ units of the flow rate (1.6 $\mathrm{mL} / \mathrm{min})$. HPLC system suitability is an important factor of HPLC analysis of antibiotics, and it ascertains the strictness of the system that is used for analysis. For 20 replicate injections of mixed standard solution samples $(0.1 \mu \mathrm{g} / \mathrm{mL}$ of each antibiotic $)$, the suitability was determined by calculating the relative standard deviations of peak areas and retention times.

\section{Sampling Sites}

Five sites (A, B, C, D, and E as shown in Fig. 2) were selected for the collection of wastewater samples. These five sites were different pharmaceutical manufacturing

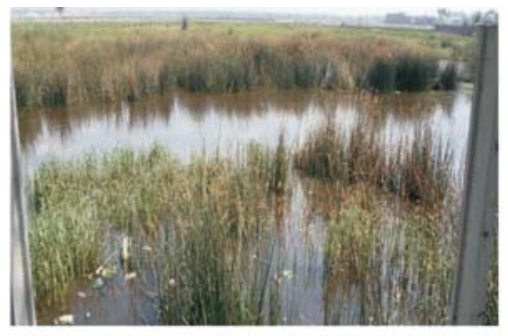

(a)

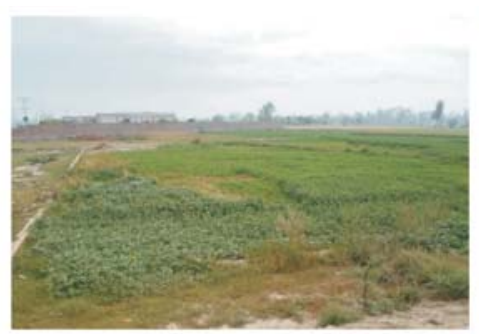

(b)

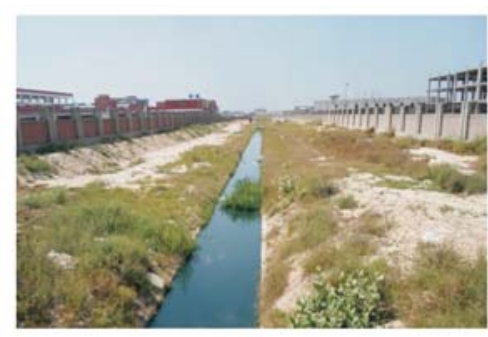

(c)

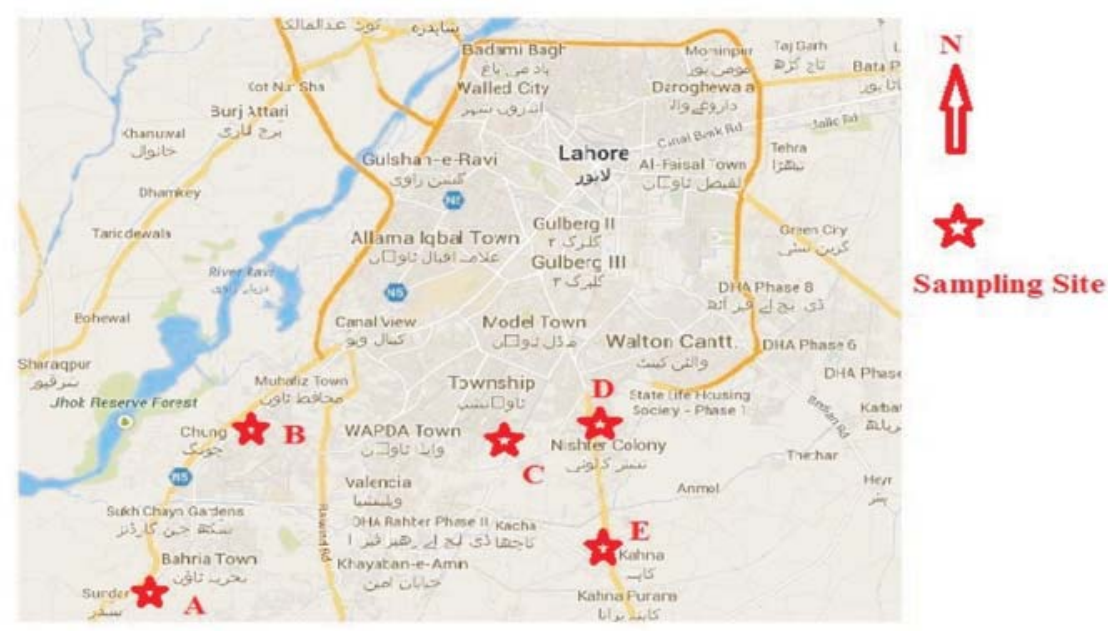

(d)

Fig. 2 (a, b, c, d). Wastewater sampling sites A, B, C, D, and E, and areas affected by wastewater. 


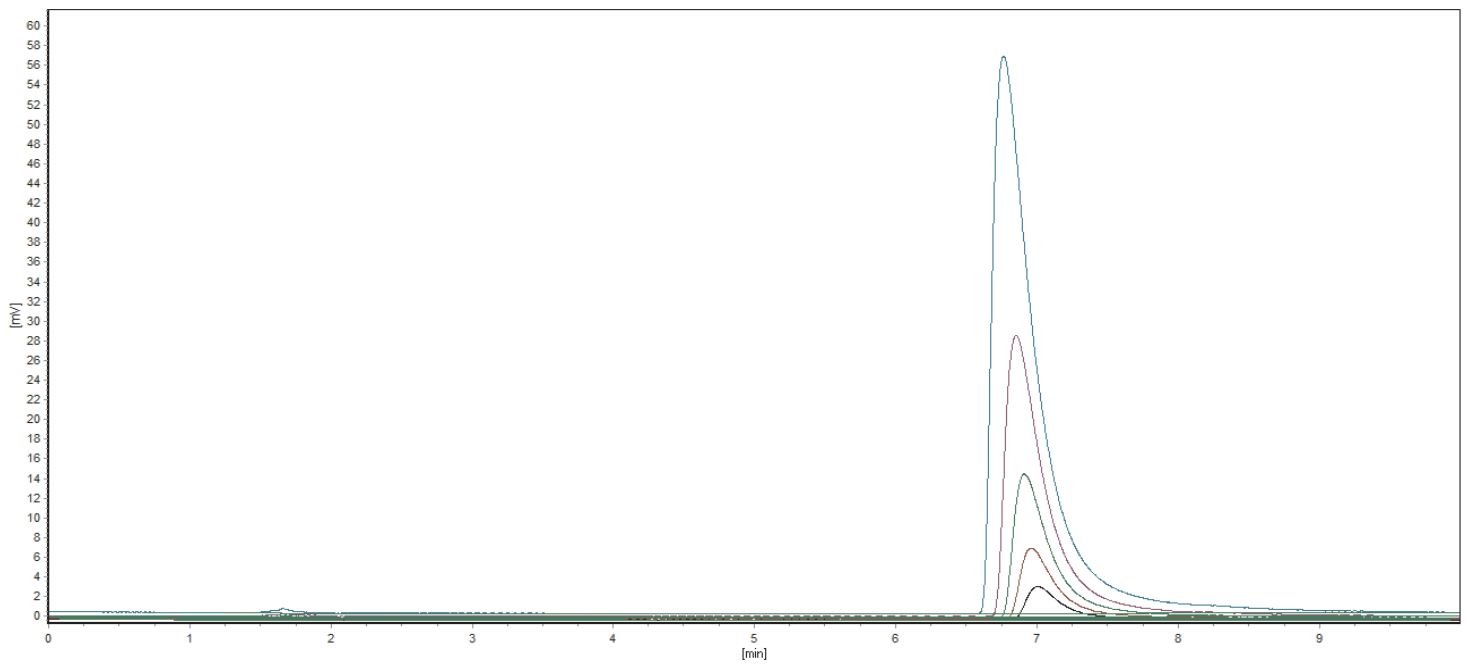

Fig. 3. Chromatogram of LEV showing peaks for different concentrations.

industrial areas of Lahore. 4.5 L of wastewater sample from each sampling point was collected into amber glass bottles, stored on ice, and brought to the laboratory within $24 \mathrm{~h}$. All samples were taken between $5^{\text {th }}$ January to $30^{\text {th }}$ 2013. Temperature and $\mathrm{pH}$ of each sample were noted at each site [16, 34]. Any kind of filtration or preservation (except for storing on ice) was not done before transfer to the laboratory. Eighteen $250 \mathrm{~mL}$ wastewater samples were taken in 30-min increments between 8 a.m. and 5 p.m., resulting in $4.5 \mathrm{~L}$ wastewater composite samples. The industrial effluent samples consisted of nine-hour (working time) composite samples. Sampling was done on each point for three different working days. Each day sample was given a separate identity.

\section{Sample Storage}

Samples were collected from raw wastewater and pharmaceutical industry effluents. To avoid bacterial contamination growth and prevent sample degradation during storage and processing, $10 \mathrm{ml}$ of $2 \mathrm{M}$ Sodium azide was added to each sample. Until filtration and extraction, the samples were retained in a refrigerator below $4^{\circ} \mathrm{C}$.

\section{Sample Preparation}

Wastewater samples collected from each site were treated for purification and each sample was passed through solid phase cartridges and eluted with methanol. Purified samples were analyzed qualitatively and quantitatively for CIP, OFL, LEV, OTC, and DOX.

\section{Qualitative Analysis}

Thin-layer chromatography (TLC) was used for the identification of antibiotics in each sample of wastewater. TLC plates were pretreated with 0.27 molar Na-EDTA solution. Then the plates were dried at $80^{\circ} \mathrm{C}$ for half an hour. The mobile phase used for TLC was chloroform: acetonitrile: methanol: 1\% ammonia (45:35:15:5). Sample and standard spots were made on TLC plates. The plates were observed under a UV lamp for separated spots [37].

\section{Quantitative Analysis}

Treated samples were analyzed quantitatively using high performance liquid chromatography (HPLC). The mobile phase was prepared by mixing acetonitrile and $0.1 \mathrm{M}$ orthophosphoric acid (13:87). The chromatographic system was equipped with a column of $25 \mathrm{~cm} \times 4.6 \mathrm{~mm}$ dimensions. Flow rate was $1.6 \mathrm{ml} / \mathrm{min}$.

\section{Results and Discussions}

\section{Optimum HPLC Conditions}

In this study five antibiotics were selected and in order to attain the separation a combination of acetonitrile and $0.1 \mathrm{M}$ orthophosphoric acid (OPA) was used as mobile phase. This study examined column temperatures $\left(\geq 20^{\circ} \mathrm{C}\right)$ and flow rates $(\geq 0.5 \mathrm{~mL} / \mathrm{min})$. Solutions of different concentrations of each antibiotic were injected

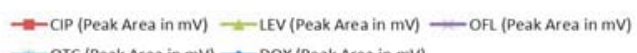
$\longrightarrow$ OTC (Peak Area in mV) $\rightarrow$ DOX (Peak Area in mV)

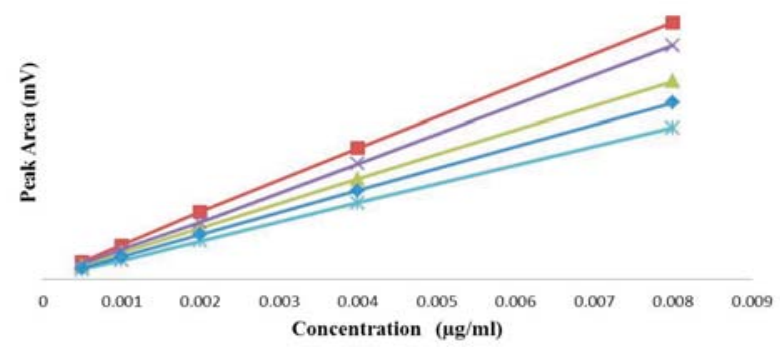

Fig. 4. Linearity graph for CIP, LEV, OFL, OTC, DOX. 
Table 1. Average concentrations of antibiotics in wastewater (in $\mathrm{mg} / \mathrm{L}$ ) of sites A to E.

\begin{tabular}{|c|c|c|c|c|c|c|c|c|}
\hline Antibiotics & $\mathrm{A}$ & $\mathrm{B}$ & $\mathrm{C}$ & $\mathrm{D}$ & $\mathrm{E}$ & Max. & Min. & Std. Dev. \\
\hline CIP & 4.75 & 4.80 & 4.65 & 3.75 & 3.87 & 5.25 & 3.00 & 0.64 \\
\hline OFL & 3.33 & 3.20 & 3.20 & 2.68 & 2.66 & 4.12 & 2.45 & 0.54 \\
\hline LEV & 3.08 & 2.04 & 3.68 & 4.25 & 3.74 & 6.20 & 0.00 & 1.91 \\
\hline OXT & 4.35 & 2.67 & 3.09 & 3.73 & 4.92 & 9.40 & 0.00 & 2.36 \\
\hline DOX & 4.78 & 3.79 & 3.65 & 3.46 & 2.34 & 6.75 & 1.58 & 1.42 \\
\hline
\end{tabular}

to HPLC with regard to the separation among the five target antibiotics and the sharpness of the peaks obtained upon injection of equal amounts. The complete separation of OTC, DOX, CIP, LEV, and OFL and their symmetrical peaks were obtained by a C-18 column $(25 \mathrm{~cm} \times 4.6 \mathrm{~mm})$ and a acetonitrile and $0.1 \mathrm{M} \mathrm{OPA}$ as mobile phase with a flow rate of $1.6 \mathrm{~mL} / \mathrm{min}$. Fig. 3 shows the resulting chromatogram of LEV obtained from the HPLC. In chromatogram of levofloxacin the five peaks are distinguished within 7.0 min (Fig. 3). The present HPLC analysis accomplished optimum separation in a minimum time without the need for a gradient system for better separation and pre-column washing after analysis.

\section{HPLC Method Validation}

Validation data for the main performance parameters of HPLC method are linearity range $0.5-8.0(\mathrm{ng} / \mathrm{ml})$, detection limit $0.05(\mathrm{ng} / \mathrm{ml})$, limit of quantification $0.5(\mathrm{ng} / \mathrm{ml})$, and coefficient of determination. R2 is 0.9998 for CIP, LEV, OFL, OTC, and DOX [38]. This data shows that the present standard stabilities and system suitability were well within the international acceptance criteria.

No effect on the peak areas was observed by the changes of $\pm 5 \%$ of the flow rate, whereas the variations in the retention times were observed with the change of flow rate. Normal retention times for OTC and DOX were 2.30, $2.6 \mathrm{~min}$, respectively, and for CIP, LEV, and OFL were 11.6, 7.0, and 12.6, respectively. At $+5 \%$ the flow rate, the three retention times were decreased (ranging between 1.6 and $4.7 \%$ for OTC and DOX), and for CIP, LEV, and OFL it decreased in the range of $1.7 \%$ and $4.5 \%$. With flow rate $-5 \%$, the times were increased, ranging between 4.8 and $9.0 \%$ for OTC and DOX, and for CIP, LEV, and OFL it increased in the range of $4.5 \%$ and $8.7 \%$. During these analyses, all the selected antibiotics were separated. Linearity graphs are shown in Fig. 4.

Table 2. Average concentrations of antibiotics in soil (in $\mu \mathrm{g} / \mathrm{kg}$ ), groundwater (in $\mu \mathrm{g} / \mathrm{kg}$ ) and plants (in $\mu \mathrm{g} / \mathrm{kg}$ ) of sampling sites A to E $[37,38]$.

\begin{tabular}{|c|c|c|c|c|c|c|}
\hline Site & Type of Sample & CIP & OFL & LEV & OXT & DOX \\
\hline \multirow[t]{3}{*}{ A } & Soil & 2.77 & 2.98 & 3.35 & 4.53 & 3.12 \\
\hline & Groundwater & 0.03 & 0.05 & 0.13 & 0.13 & 0.36 \\
\hline & Plants & 0.94 & 0.95 & 0.98 & 1.00 & 0.90 \\
\hline \multirow[t]{3}{*}{ B } & Soil & 2.03 & 3.47 & 2.92 & 2.97 & 2.47 \\
\hline & Groundwater & 0.12 & 0.10 & 0.13 & 0.08 & 0.23 \\
\hline & Plants & 0.92 & 1.06 & 1.34 & 0.82 & 0.87 \\
\hline \multirow[t]{3}{*}{$\mathrm{C}$} & Soil & 3.51 & 2.95 & 1.92 & 3.74 & 2.46 \\
\hline & Groundwater & 0.04 & 0.05 & 0.10 & 0.08 & 0.03 \\
\hline & Plants & 0.67 & 1.09 & 1.04 & 0.96 & 2.67 \\
\hline \multirow[t]{3}{*}{$\mathrm{D}$} & Soil & 2.80 & 3.83 & 4.62 & 2.33 & 2.00 \\
\hline & Groundwater & 0.05 & 0.23 & 0.10 & 0.09 & 0.15 \\
\hline & Plants & 0.73 & 1.23 & 1.16 & 0.67 & 1.07 \\
\hline \multirow[t]{3}{*}{ E } & Soil & 3.17 & 4.67 & 2.06 & 2.83 & 2.35 \\
\hline & Groundwater & 0.11 & 0.05 & 0.00 & 0.11 & 0.07 \\
\hline & Plants & 0.65 & 1.50 & 0.72 & 1.21 & 0.97 \\
\hline
\end{tabular}




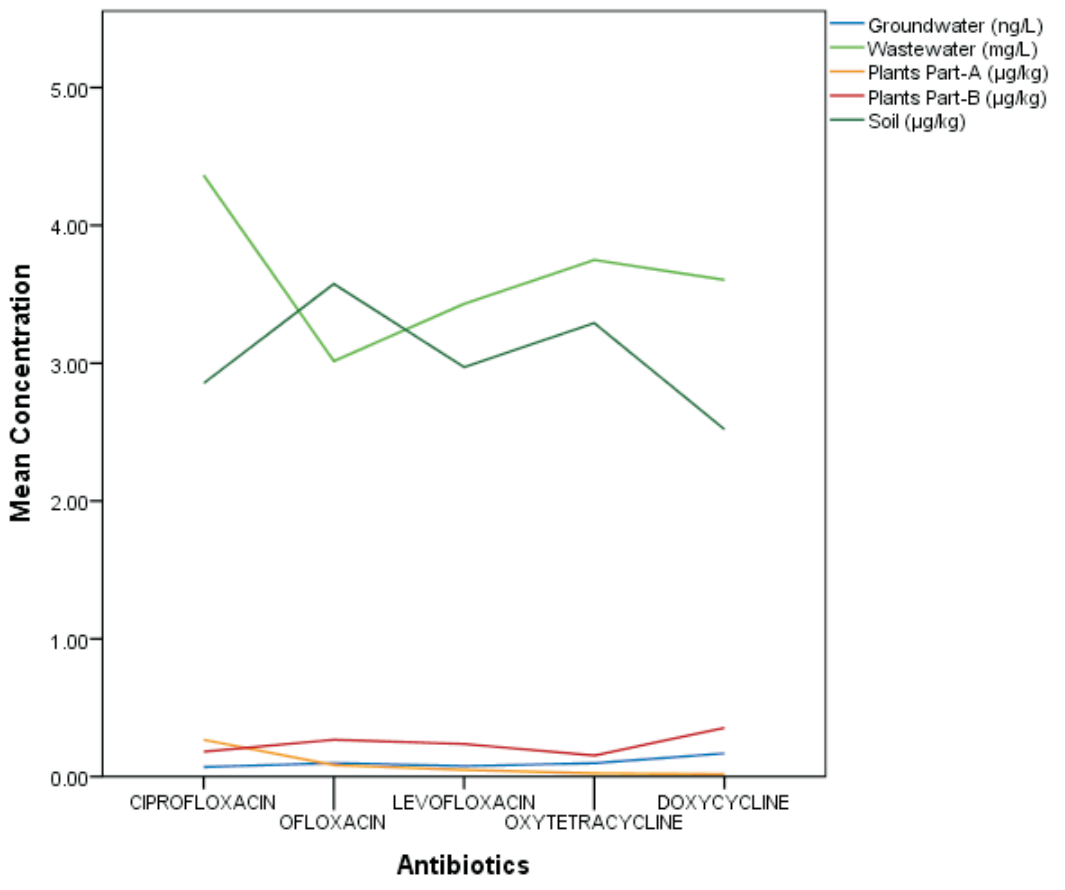

Fig. 5. Graphical representation of average concentrations of antibiotics.

\section{Sample Analysis}

Three samples of wastewater from each of five sampling sites were analysed for determination of residual levels of selected antibiotics. It was observed that wastewater sample B-1 has the highest level of CIP $(5.25 \mathrm{mg} / \mathrm{L})$, the highest level of $\mathrm{OFL}$ is in $\mathrm{C}-1$ (4.12 $\mathrm{mg} / \mathrm{L})$, the highest level of LEV is in C-2 (6.2 mg/L), the highest level of OTC is in A-2 $(9.4 \mathrm{mg} / \mathrm{L})$, and the highest level of DOX is in B-1 $(6.75 \mathrm{mg} / \mathrm{L})$ (Tables 1 and 2).

Site A was found to be most contaminated by selected antibiotics levels and site $\mathrm{B}$ the least. The descending order of total contamination level of sampling sites is $\mathrm{A}>\mathrm{C}>\mathrm{D}>\mathrm{E}>\mathrm{B}$. In wastewater sample contamination levels the order of sampling sites is $\mathrm{A}>\mathrm{C}>\mathrm{D}>\mathrm{E}>\mathrm{B}$.

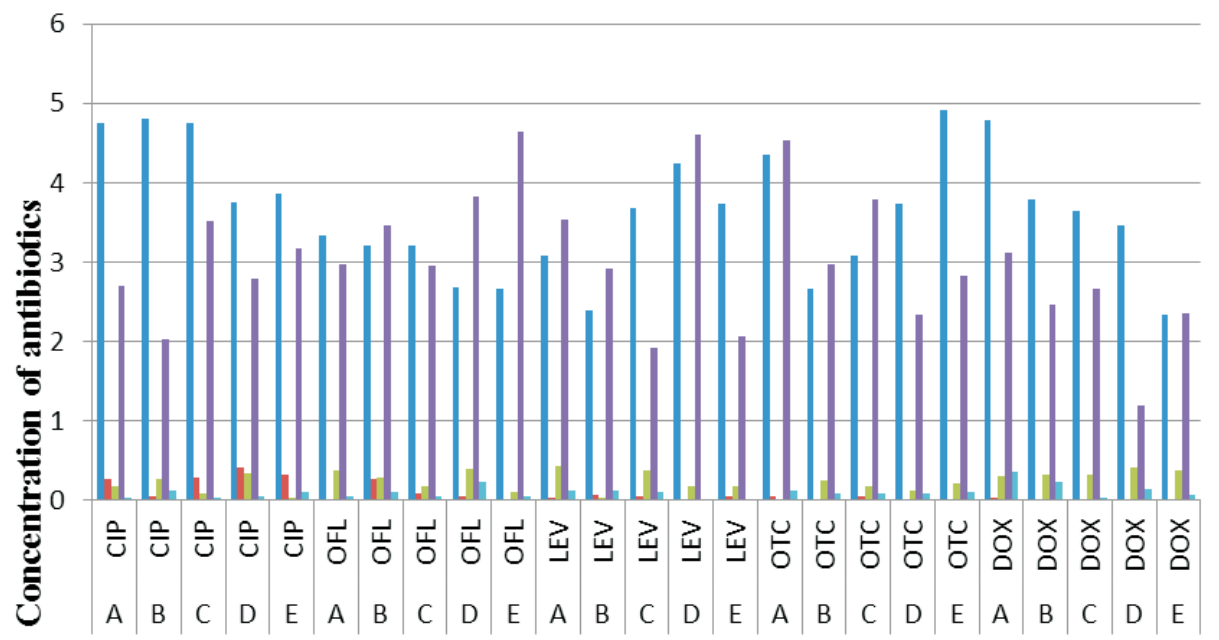

Antibiotics in Sampling Site A, B, C, D, E.

Concentration in Wastewater $\quad$ Concentration in Plants Part A
Concentration in Plants Part B $\quad$ Concentration in Soil
Concentration in Ground Water

Fig. 6. Average concentraions of antibiotics in wastewater (in $\mathrm{mg} / \mathrm{L}$ ), soil (in $\mu \mathrm{g} / \mathrm{kg}$ ), plants (in $\mu \mathrm{g} / \mathrm{kg}$ ), and groundwater (in ng/L) samples of sites A, B, C, D, E. 
All five sampling sites see the highest levels of contamination in wasterwater. The descending order of contamination of type of sample from all five sites is wastewater $>$ soil $>$ plants part-B $>$ plants part-A $>$ groundwater. At sampling site $A$ the order of contamination level of antibitics according to type of antibiotic is DOX $>$ CIP $>$ OTC > LEV > OFL. At sampling site B the order of contamination level of antibitics according to type of antibiotics is as CIP $>$ DOX $>$ LEV $>$ OTC $>$ OFL. At sampling site $\mathrm{C}$ order of contamination level of antibitics according to type of antibiotic is CIP $>$ OFL $>$ OTC $>$ LEV $>$ DOX. At sampling site D the order of contamination level of antibitics according to type of antibiotics is OFL $>$ DOX $>$ LEV $>$ CIP $>$ OTC. At sampling site E the order of contamination level of antibitics according to type of antibiotic is $\mathrm{LEV}>\mathrm{DOX}>\mathrm{OFL}>\mathrm{TC}>\mathrm{CIP}$. A comparison of antibiotic levels is shown in Figs 5 and 6.

\section{Conclusions}

A method for determining residual levels of OTC, DOC, CIP, LEV, and OFL in wastewater was validated on HPLC with a DAD detector using acetonitrile and $0.1 \mathrm{M}$ OPA $(13: 87, \mathrm{v} / \mathrm{v})$ as mobile phase. The method was evaluated on different parameters or ICH guidelines, i.e., LOQ, LOD, robustness, linearity, and system suitability, and it obtained good results. Antibiotics are a major source of contamination that reduce immunity in people as well as animals. Humans take antibiotics directly or indirectly from food items, meat, milk, and vegetables, etc., and these are accumulated in the body. Acetonitrile and the $0.1 \mathrm{M}$ OPA combination as mobile phase used in this method is useful for determining residual levels of antibiotics in environmental, groundwater, and food samples, and it has a short run time and high sensitivity. For measuring various food, environmental, and groundwater samples the proposed HPLC method was applied by adopting a suitable sample preparation method.

We found that five out of five selected sites were contaminated by these antibiotics. The residual levels were found in the range $0-9.40 \mathrm{mg} / \mathrm{L}$ in wastewater, 0-5.41 $\mu \mathrm{g} / \mathrm{kg}$ in soil, $0-0.60 \mu \mathrm{g} / \mathrm{kg}$ in part A of plants, $0-0.98 \mu \mathrm{g} /$ $\mathrm{kg}$ in part $\mathrm{B}$ of plants, and $0-0.80 \mathrm{ng} / \mathrm{L}$ in groundwater samples. Higher levels of residues were detected for LEV from Fluoroquinolones with residual levels of $6.20 \mathrm{mg} / \mathrm{L}$ and OTC (tetracycline), with maximum residual levels of $9.40 \mathrm{mg} / \mathrm{L}$ in the industrial wastewater. OFL $5.41 \mu \mathrm{g} / \mathrm{kg}$ and OTC $5.06 \mu \mathrm{g} / \mathrm{kg}$ were the highest levels of residues determined in the soil affected by industrial wastewater [38]. CIP and LEV $(0.60 \mu \mathrm{g} / \mathrm{kg})$ and OTC $(0.07 \mu \mathrm{g} / \mathrm{kg})$ were the highest levels of residues in part A of the plants irrigated by water that is contaminated by industrial wastewater [37]. The highest contamination level was observed for OFL with a value of $0.98 \mu \mathrm{g} / \mathrm{kg}$ and DOX with value of $0.71 \mu \mathrm{g} / \mathrm{kg}$ in part B of the plants irrigated by water that is contaminated by industrial wastewater [37]. The highest concentration was observed for ofloxacin from fluoroquinolones class with maximum contamination level of $0.50 \mathrm{ng} / \mathrm{L}$, and Doxycycline (tetracycline) class with maximum residual level of $0.80 \mathrm{ng} / \mathrm{L}$ in the underground water samples in surrounding areas affected by industrial wastewater [38].

The results show that wastewater is contaminated more than the other types of samples (plants, soil, and groundwater) as wastewater is the main pathway for bringing antibiotics to the environment. Soil is the second most-contaminated segment among these samples and plays an important role in accumulating these antibiotics for plants and leaching them to groundwater.

\section{Acknowledgements}

Authors would like to thank the Pakistan Council of Scientific and Industrial Research (PCSIR) Labs Complex, Ferozpur Road Lahore, and the College of Earth and Environmental Sciences (CEES), University of the Punjab, Lahore, for all laboratory facilities used for sample preparation and analysis during this research. This work has been supported financially by the Higher Education Commission of Pakistan (HEC), through grant No. 106-1762-Ps6-059.

\section{References}

1. NAKATA H., KANNAN K., JONES P.D., GIESY J.P. Determination of fluoroquinolone antibiotics in wastewater effluents by liquid chromatography-mass spectrometry and fluorescence detection. Chemosphere. 58, (6), 759, 2005.

2. GOLET E.M., ALDER A.C., GIGER W. Environmental exposure and risk assessment of fluoroquinolone antibacterial agents in wastewater and river water of the Glatt Valley Watershed, Switzerland. Environmental Science \& Technology. 36, (17), 3645, 2002.

3. CHANG X., MEYER M.T., LIU X., ZHAO Q., CHEN H., CHEN J.A., QIU Z., YANG L., CAO J., SHU W. Determination of antibiotics in sewage from hospitals, nursery and slaughter house, wastewater treatment plant and source water in Chongqing region of Three Gorge Reservoir in China. Environ Pollut. 158 (5), 1444, 2010.

4. HU X., ZHOU Q., LUO Y. Occurrence and source analysis of typical veterinary antibiotics in manure, soil, vegetables and groundwater from organic vegetable bases, northern China. Environ Pollut. 158 (9), 2992, 2010.

5. SUN J., LI W., ZHENG P., ZHU J. Toxicity Evaluation of Antibiotics in Piggery Wastewater by Luminescent Bacteria. Polish Journal of Environmental Studies. 21 (3), 641, 2012.

6. SARMAH A.K., MEYER M.T., BOXALL A.B. A global perspective on the use, sales, exposure pathways, occurrence, fate and effects of veterinary antibiotics (VAs) in the environment. Chemosphere. 65 (5), 725, 2006.

7. LIU J.L. WONG M.H. Pharmaceuticals and personal care products (PPCPs): a review on environmental contamination in China. Environ Int. 59, 208, 2013.

8. MACEDO A.S., FREITAS A.R., ABREU C., MACHADO E., PEIXE L., SOUSA J.C., NOVAIS C. Characterization of antibiotic resistant enterococci isolated from untreated waters for human consumption in Portugal. Int $\mathrm{J}$ Food Microbiol. 145 (1), 315, 2011. 
9. WALCZAK M., DONDERSKI W. Antibiotic Sensitivity of Neustonic Bacteria in Lake Jeziorak Mały. Pol. J. Environ. Stud. 13 (4), 429, 2004.

10. MANZETTI S. GHISI R. The environmental release and fate of antibiotics. Mar Pollut Bull. 79 (1-2), 7, 2014.

11. HOA P.T., MANAGAKI S., NAKADA N., TAKADA H., SHIMIZU A., ANH D.H., VIET P.H., SUZUKI S. Antibiotic contamination and occurrence of antibiotic-resistant bacteria in aquatic environments of northern Vietnam. Sci Total Environ. 409 (15), 2894, 2011.

12. SWIĘCIŁO A., ZYCH-WĘŻYK I. Bacterial Stress Response as an Adaptation to Life in a Soil Environment. Polish Journal of Environmental Studies. 22 (6), 1577, 2013.

13. GLASSMEYER S.T., HINCHEY E.K., BOEHME S.E., DAUGHTON C.G., RUHOY I.S., CONERLY O., DANIELS R.L., LAUER L., MCCARTHY M., NETTESHEIM T.G., SYKES K., THOMPSON V.G. Disposal practices for unwanted residential medications in the United States. Environ Int. 35 (3), 566, 2009.

14. BROWN K.D. Pharmaceutically active compounds in residential and hospital effluent, municipal wastewater, and the Rio Grande in Albuquerque, New Mexico. 2011.

15. GODFREY E., WOESSNER W.W., BENOTTI M.J. Pharmaceuticals in On-Site Sewage Effluent and Ground Water, Western Montana. Ground Water. 45 (3), 263, 2007.

16. BROWN K.D., KULIS J., THOMSON B., CHAPMAN T.H., MAWHINNEY D.B. Occurrence of antibiotics in hospital, residential, and dairy effluent, municipal wastewater, and the Rio Grande in New Mexico. Sci Total Environ. 366 (2-3), 772, 2006.

17. OBST U., SCHWARTZ T., VOLKMANN, H. Antibiotic resistant pathogenic bacteria and their resistance genes in bacterial biofilms. The International journal of artificial organs. 29 (4), 384, 2006.

18. HANSON M.L., KNAPP C.W., GRAHAM D.W. Field assessment of oxytetracycline exposure to the freshwater macrophytes Egeria densa Planch. and Ceratophyllum demersum L. Environ Pollut. 141 (3), 434, 2006.

19. SELVARATNAM S. KUNBERGER J.D. Increased frequency of drug-resistant bacteria and fecal coliforms in an Indiana Creek adjacent to farmland amended with treated sludge. Can J Microbiol. 50 (8), 653, 2004.

20. BAQUERO F., MARTINEZ J.L., CANTON R. Antibiotics and antibiotic resistance in water environments. Curr Opin Biotechnol. 19 (3), 260, 2008.

21. ABDALLAH S.A. Detection and Differentiation of Escherichia coli Populations from Human, Animal and Avian Feces, and Different Water Sources. Pol. J. Environ. Stud. 14 (5), 639, 2005.

22. SENDZIK J., SHAKIBAEI M., SCHÄFER-KORTING M., and STAHLMANN, R. Fluoroquinolones cause changes in extracellular matrix, signalling proteins, metalloproteinases and caspase- 3 in cultured human tendon cells. Toxicology. 212 (1), 24, 2005.

23. PARK S. CHOI K. Hazard assessment of commonly used agricultural antibiotics on aquatic ecosystems. Ecotoxicology. 17 (6), 526, 2008.

24. POMATI F., CASTIGLIONI S., ZUCCATO E., FANELLI R., VIGETTI D., ROSSETTI C., CALAMARI D. Effects of a complex mixture of therapeutic drugs at environmental levels on human embryonic cells. Environmental science \& technology. 40 (7), 2442, 2006.
25. FANG H., HAN Y., YIN Y., PAN X., YU Y. Variations in dissipation rate, microbial function and antibiotic resistance due to repeated introductions of manure containing sulfadiazine and chlortetracycline to soil. Chemosphere. 96, 51, 2014.

26. MUDRYK Z.J. Antibiotic Resistance among Bacteria Inhabiting Surface and Subsurface Water Layers in Estuarine Lake Gardno. Polish Journal of Environmental Studies. 11, (4), 401, 2002.

27. HUANG C.H., SEDLAK D.L. Analysis of estrogenic hormones in municipal wastewater effluent and surface water using enzyme-linked immunosorbent assay and gas chromatography/tandem mass spectrometry. Environmental Toxicology and Chemistry. 20 (1), 133-, 2001.

28. WANG F.H., QIAO M., LV Z.E., GUO G.X., JIA Y., SU Y.H., ZHU Y.G. Impact of reclaimed water irrigation on antibiotic resistance in public parks, Beijing, China. Environ Pollut. 184, 247, 2014.

29. MCNEECE G., NAUGHTON V., WOODWARD M.J., DOOLEY J.S., NAUGHTON P.J. Array based detection of antibiotic resistance genes in Gram negative bacteria isolated from retail poultry meat in the UK and Ireland. Int J Food Microbiol. 179, 24, 2014.

30. YANG C.W., CHANG Y.T., CHAO W.L., SHIUNG II, LIN H.S., CHEN H., HO S.H., LU M.J., LEE P.H., FAN S.N. An investigation of total bacterial communities, culturable antibiotic-resistant bacterial communities and integrons in the river water environments of Taipei city. J Hazard Mater. 2013.

31. CARLSON J.C., MABURY S.A. Dissipation kinetics and mobility of chlortetracycline, tylosin, and monensin in an agricultural soil in Northumberland County, Ontario, Canada. Environmental toxicology and chemistry. 25 (1), 1, 2006.

32. WU X., WEI Y., ZHENG J., ZHAO X., ZHONG W. The behavior of tetracyclines and their degradation products during swine manure composting. Bioresour Technol. 102 (10), 5924, 2011.

33. PAN X., QIANG Z., BEN W., CHEN M. Residual veterinary antibiotics in swine manure from concentrated animal feeding operations in Shandong Province, China. Chemosphere. 84 (5), 695, 2011.

34. TONG L., LI P., WANG Y., ZHU K. Analysis of veterinary antibiotic residues in swine wastewater and environmental water samples using optimized SPE-LC/MS/MS. Chemosphere. 74 (8), 1090, 2009.

35. ZAMAN K. Review of Pakistan Pharmaceutical Industry: SWOT Analysis. International Journal of Business and Information Technology. 1 (2), 2011.

36. BARNES K.K., KOLPIN D.W., MEYER M.T., THURMAN E.M., FURLONG E.T., ZAUGG S.D., BARBER L.B. Water-quality data for pharmaceuticals, hormones, and other organic wastewater contaminants in US streams, 1999-2000. 2002: US Department of the Interior, US Geological Survey.

37. HUSSAIN S., NAEEM M., CHAUDHRY M.N.,IQBAL M.A. Accumulation of Residual Antibiotics in the Vegetables Irrigated by Pharmaceutical Wastewater. Exposure and Health. 2015.

38. HUSSAIN S., NAEEM M., CHAUDHRY M.N. Estimation of residual antibiotics in soil and underground water of areas affected by pharmaceutical wastewater in Lahore. Journal of Water Chemistry and Technology. 2015. 